\title{
種々の豆類種子のアリューロン層の構造と その高グリシンタンパク質含有量
}

\author{
松 井 美預子, 中 井 理 江 \\ 豊 沢 功, 福 田 満 \\ 武庫川女子大学生活環境学部食物栄赛学科
}

\begin{abstract}
The Structure of the Aleurone Layer and Its Glycine-rich Protein Content in Different Bean Seeds

Miyoko MATSUI, Rie NAKAI, Isao TOYOSAWA and Mitsuru FUKUDA

Department of Food Science and Nutrition, School of Life and Environmental Sciences, Mukogawa Women's University, Nishinomiya 663
\end{abstract}

Nippon Eiyō Shokuryō Gakkaishi (J. Jpn. Soc. Nutr. Food Sci.) 48, 477 483 (1995)

The tissue structure of the aleurone layer in different bean seeds, and its content of the glycine-rich protein (GRP) were investigated. The aleurone layers of soybean (Glycine max, cv. Enrei), black soybean (Glycine max, cv. Tanbaguro), and wild soybean (Glycine soja) were thicker compared to those of red kidney bean (Phaseolus vulgaris, cv. Taishokintoki) and marbled kidney bean (Phaseolus vulgaris, cv. Toramame). The soybean GRP, which is a characteristic of the cell walls in the aleurone layer, was found mainly in the pectin fraction. The GRP content, found in the hot-water-soluble fraction of the aleurone layer, in the three kinds of soybean was greater than that found in the two kinds of kidney bean. The estimated molecular size (about $30 \mathrm{kDa}$ ) of the GRPs extracted from both the wild and black soybeans was the same as that from Glycine max, cv Enrei. The GRP, found in the aleurone layer of plants belonging to the soybean genus, probably has some role in strengthening the cell walls in this tissue.

Key Words aleurone layer, glycine-rich protein, cell wall protein, soybean genus, pectin.

(Received April 6, 1995)

\begin{abstract}
種子の吸水は種子を原料とする加工食品の紫造や稿子 の発芽・栽培を行う上で非常に重要な性冝である。タイ スの種皮は他の豆に比へて薄いのて，稙皮表面から水分 が容易に吸収される。著者らはダイズ程子の吸水機䅇を 研究する目的でダイス種皮やアリューロン曽の粗造と成 分を調へる過程において, 種皮に付随するアリューロン 居" に高グリシンタンパク實 (GRP) が存在することを 認めた2)。GRP は植物および動物組織に存在しる，織維状 構造の形成率の高いタンパク質であるい。また GRP は植 物組織内ては細胞壁の構造タンパク䨘であり，最近種々 の植物に GRP およびその造层子の存在が報告されてい

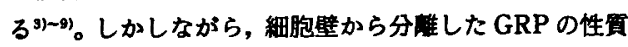

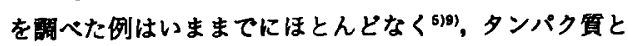
しての性實の解明が必要とされる。一方, 植物組織全体 の細胞碒にはヒドロキシプロリン量の曾富なタンパク質
\end{abstract}

(エクステンシン ${ }^{10)-12)}$ やプロリン年の量富なタンパク 筫 ${ }^{13)}$ が存在するが, GRP の分布は植物内の維管束等の

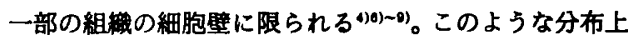
の相蛙から，両者は細胞壁内で異なった役割を担ってい ると推定される。また, GRP は植物のストレスタンパク

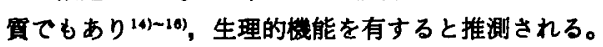

著者らは先にタイイス和子のアリューロン虽細胞壁の熱 水可溶性画分から GRPの分離精製を行ったが(17)18)，ア リューロン居 GRP の細胞垶内機能についてはいまだ明 らかになっていない。本論文では豆類アリューロン居に おける GRP の機能解明のために，ダイスやインゲンマ メのアリューロン周組織㩐造の比較, ダイスのアリュー ロン居 GRPの細胞壁内分布, タイス以外の豆のア リューロン周細胞壁ての GRP の存在を調へた。

厂 663 西宮市池開町 6-46 


\section{実験材料と方法}

\section{1. 実験材料と程皮・アリューロン局の組織钼察}

市販のダイス (品種エンレイ), 黒タイス (品種タンバ グロ), インゲンマメ(品種タイショウキントキ), イン ダンマメ(品種トラマメ), さらに奈良県て栽培し収穝し たツルマメ(タイイスの野生種)を実駼材料として用いた。

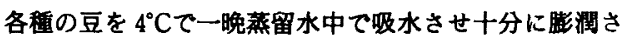
せた後、アリューロン居とともに種皮組織を種子から剥 離し凍結乾燥した。この配燥試料の種皮のへそを含まな

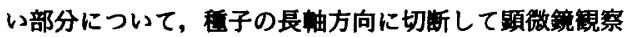
用の試料とした。試料は金蒸着後, $20 \mathrm{kV}$ て走査型電子 顕微鏡（日立，S-530)によってその組織断面を䂓察した。

2. アリューロン苗の採取

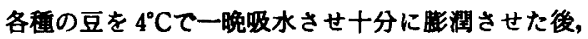
先にアリューロン層の付いた種皮を别離後, 種皮から海 綿状柔組織を合まないように注意しながらアリューロン 首を分離し採取した。次にアリューロン首を凍結乾燥し た。アリューロン層組織の純度の確認は, 前報18) と同様 に走査型電子影微篭（日立, S-530) と光学影微鏡により 行った。

\section{3. 淍胞億中の請画分の分画}

1.000 粒のダイス種子（品種エンレイ）から得た $2.5 \mathrm{~g}$ の凍結乾燥アリューロン層を試料として, 既報2) と同様 にして $80^{\circ} \mathrm{C}$ 熱水を用いて熱水可溶性画分を分離した (ペクチンI画分)。その残查から, 既報19)に従って, $80 \sim 85^{\circ} \mathrm{C}$ で $0.25 \mathrm{M}$ シュウ酸アンモニウムーシュウ酸 $(\mathrm{pH}$ 4.0)による抽出 (ペクチン II 画分), 窒素気流下で $26^{\circ} \mathrm{C}$ で5\% KOHによる抽出 (へミセルロースI画分), 同様

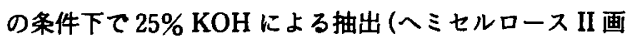
分）を順次行ってそれぞれの画分を得た。さらに最後の 抽出残渣をセルロース画分とした。各画分を透析した後 涷結乾燥した。

4. アリューロン腐タンパク画画分の分椎

既報りに従い, 各盾の豆種子から分崔したアリューロ ン屏の東結乾燥物 $1 \mathrm{~g}$ を粉碎した後に洗净し, 100 倍量 の $80^{\circ} \mathrm{C}$ 熱水て 2 回抽出して熱水可溶性画分 (ペクチン I 画分) を得た。この熱水可溶性画分を $0.05 \mathrm{M} ト$ ト - $\mathrm{HCl}$ 緩衙液 $(\mathrm{pH}$ 8.0) によって平衖化した DEAE-セ ファデックスカラム $(1.5 \times 4.0 \mathrm{~cm})$ に吸着させ, 非吸着 タンパク質を洗浄除去した後, $0.5 \mathrm{M} \mathrm{NaCl}$ を含む同緩筕 液で溶出してアリューロン眉タンパク質画分を得た。

5. アミノ酸分析

抽出および分離したタンパク䨘を $6 \mathrm{~N} \mathrm{HCl}$ 中で $110^{\circ} \mathrm{C}, 24$ 時間加水分解した後, 日立 835 型アミノ酸分析 計で分析してアミノ酸組成を求めた。な扔, シスチンは システイン酸として求めた。細胞壁諸画分, 熱水可溶性
画分，アリューロン晍タンパク異画分の調製はそれぞれ 5 回ずつ行い，それそれの調製画分についてアミノ酸分 析を実施し，平均土標菹偏差としてアミノ酸組成を求め た。

\section{GRPの分子至}

各種の豆種子のアリューロン首タンパク質画分それぞ れを透析した後に凍結乾燥したものを $0.1 \mathrm{M} \mathrm{NaCl}$ に溶 解し, セファデックス G-100 カラム $(1.0 \times 100 \mathrm{~cm})$ て $0.1 \mathrm{M} \mathrm{NaCl}$ を溶媒として $0.5 \mathrm{ml} /$ 分の流速でル゙渞過 を行い, 1 フラクション $2.7 \mathrm{ml}$ ずつ分取した。各フラク ションのアミノ酸分析の結果よりグリシンモル比 (\%) を求め, GRP の溶出位置と分子量を求めた。

\section{実験結果と考察}

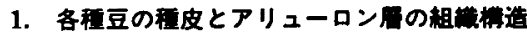

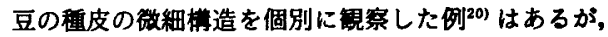
各種の豆のアリューロン首の検造を比較した例を過去に 見ない。一般に豆類では種子の成热過程で胚乳組織が退 化し，アリューロン届が子莱組織を被うことになる。各 種の豆の種皮とアリューロン首組織の断面について走査 型電子䫓微鏡で調へた結果, Fig. 1(A-E)に示す組織桡 造が観察された。各種の豆種子の種皮組織の内層（写真 の種皮下層，海綿状柔組織）に接してアリューロン層の 存在が認められたが, 胚乳残存組織の存在 ${ }^{11}$ は䚁察され なかった。ダイス (エンレイ) (A) と黒ダイス (タンバ グロ（B）ては種皮部分の柱状細胞（砂時計型細胞）が とりわけ発達しているのが特徽的てあった。種皮組織の 厚さと比へればアリューロン層は相対的に薄いか，各種 の豆を互いに比較すると，アリューロン層の組織構造は ダイス (エンレイ) (A) て最も厚く発達していることが 明らかであった。また，黒タイス(タンバグロ（B)ゃ ツルマメ(C) てもかなり厚みのあるアリューロン届組織 でった。しかしながら、インダンマメ(タイショウキ ントキ)(D)やインゲンマメ(トラマメ)(E)ではアリュー ロン層はやや薄く均一な厚さを示さず，ところどころ途 切れ，あまり発達した状態てはなかった。

一方，種皮からアリューロン層を分離して採取する際 にダイス属の豆てはアリューロン㕣が断片化せずに 1 枚 の膜として郘離することが可能であったが，インゲンマ メ属の豆てはアリューロン層が壊れやすく断片化したこ とからも，その組織の強度がインゲンマメ属の豆ては劣 ると考えられる。また,アリューロン層付種皮組織加ら 分離したアリューロン層（乾燥重量）の収率をアリュー ロン層付種皮組織の乾燥重量あたりで表すと,ダイス (エンレイ), 黒タイス (タンパグロ), ッルマメでは約 10\%になり，インダンマメ(タイショウキントキ, トラ マメ)ではアリューロン層が潧くて分踓しにくく断片化 

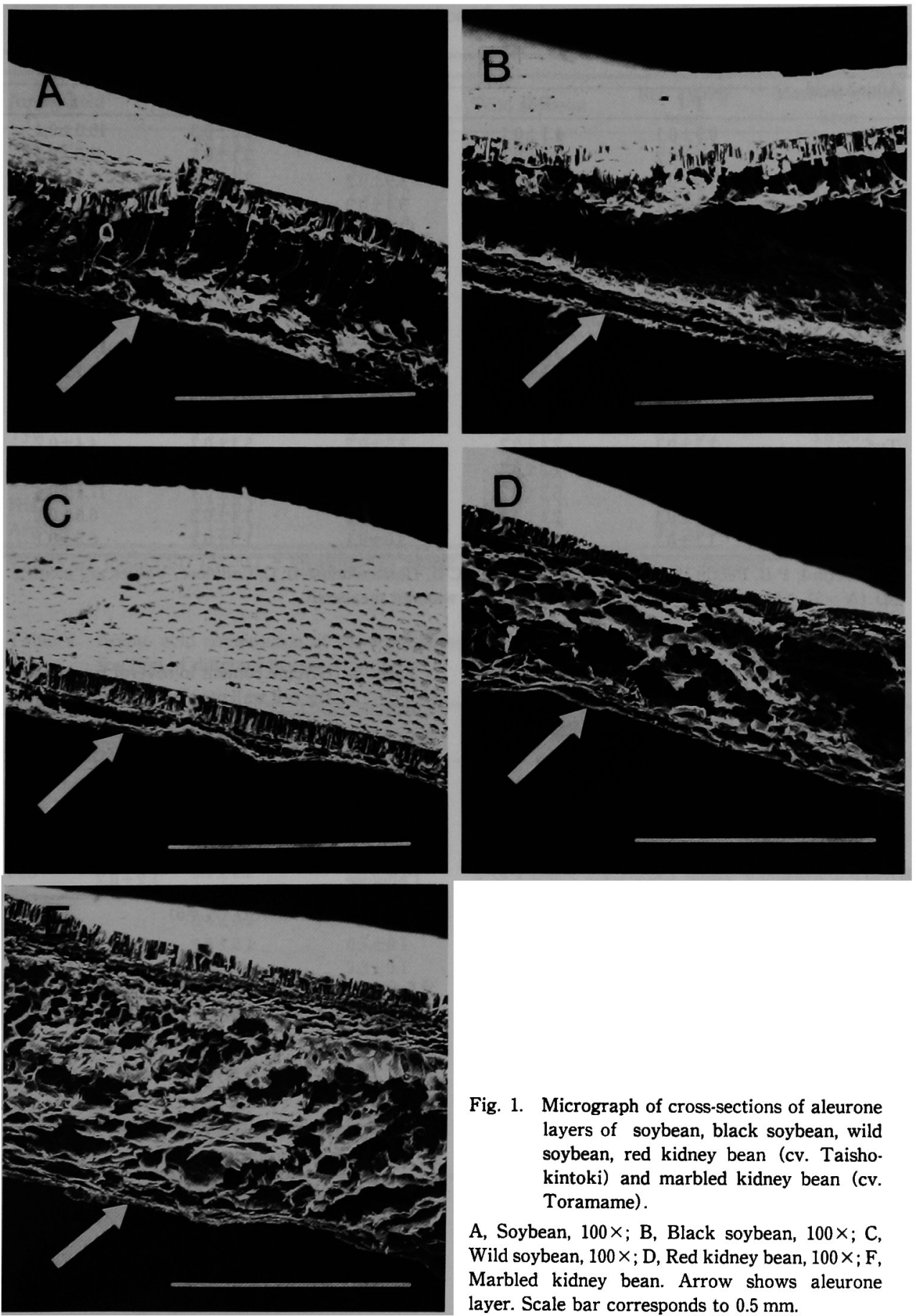

Fig. 1. Micrograph of cross-sections of aleurone layers of soybean, black soybean, wild soybean, red kidney bean (cv. Taishokintoki) and marbled kidney bean (cv. Toramame).

A, Soybean, 100x; B, Black soybean, 100x; C, Wild soybean, $100 \times$; D, Red kidney bean, $100 \times$; F, Marbled kidney bean. Arrow shows aleurone layer. Scale bar corresponds to $0.5 \mathrm{~mm}$. 
Table 1. Amino acid composition of several fractions in the cell wall of soybean aleurone layer.

(molar \%)

\begin{tabular}{|c|c|c|c|c|c|}
\hline \multirow{2}{*}{ Amino acid } & \multicolumn{5}{|c|}{ Fraction } \\
\hline & P-I & P-II & HC-I & HC-II & $\mathrm{C}$ \\
\hline Hyp & $0.9 \pm 0.1$ & $1.1 \pm 0.1$ & $2.6 \pm 0.2$ & $16.6 \pm 0.3$ & $19.0 \pm 0.4$ \\
\hline Asx & $7.2 \pm 0.2$ & $7.3 \pm 0.1$ & $10.3 \pm 0.3$ & $5.1 \pm 0.1$ & $2.5 \pm 0.2$ \\
\hline Thr & $1.9 \pm 0.2$ & $4.1 \pm 0.2$ & $3.9 \pm 0.2$ & $2.1 \pm 0.2$ & $1.1 \pm 0.1$ \\
\hline Ser & $11.2 \pm 0.2$ & $10.3 \pm 0.3$ & $5.4 \pm 0.2$ & $4.0 \pm 0.2$ & $1.4 \pm 0.2$ \\
\hline Glx & $7.7 \pm 0.3$ & $9.9 \pm 0.3$ & $12.0 \pm 0.4$ & $10.4 \pm 0.3$ & $9.9 \pm 0.3$ \\
\hline Pro & $2.8 \pm 0.2$ & $4.0 \pm 0.2$ & $6.2 \pm 0.2$ & $12.1 \pm 0.3$ & $16.9 \pm 0.5$ \\
\hline Gly & $47.3 \pm 0.7$ & $34.7 \pm 0.6$ & $13.3 \pm 0.4$ & $7.8 \pm 0.3$ & $5.4 \pm 0.3$ \\
\hline Ala & $5.6 \pm 0.2$ & $6.9 \pm 0.3$ & $6.7 \pm 0.1$ & $3.7 \pm 0.2$ & $1.4 \pm 0.2$ \\
\hline $1 / 2 \mathrm{Cys}^{\mathrm{a}}$ & $0.6 \pm 0.1$ & $0.2 \pm 0.1$ & $0.1 \pm 0.0$ & $0.1 \pm 0.0$ & $0.2 \pm 0.1$ \\
\hline Val & $2.1 \pm 0.2$ & $4.3 \pm 0.1$ & $7.6 \pm 0.2$ & $11.6 \pm 0.4$ & $16.3 \pm 0.4$ \\
\hline Met & $0.4 \pm 0.1$ & $0.4 \pm 0.1$ & $0.8 \pm 0.1$ & $0.5 \pm 0.1$ & $0.1 \pm 0.0$ \\
\hline Ile & $1.5 \pm 0.3$ & $2.0 \pm 0.1$ & $4.4 \pm 0.1$ & $2.2 \pm 0.2$ & $1.4 \pm 0.2$ \\
\hline Leu & $1.6 \pm 0.1$ & $2.1 \pm 0.2$ & $7.1 \pm 0.2$ & $2.4 \pm 0.2$ & $1.2 \pm 0.1$ \\
\hline Tyr & $1.3 \pm 0.1$ & $2.4 \pm 0.2$ & $3.5 \pm 0.2$ & $5.4 \pm 0.2$ & $4.4 \pm 0.2$ \\
\hline Phe & $1.1 \pm 0.1$ & $1.3 \pm 0.2$ & $3.8 \pm 0.2$ & $2.0 \pm 0.2$ & $0.8 \pm 0.1$ \\
\hline Lys & $4.3 \pm 0.3$ & $5.3 \pm 0.2$ & $7.5 \pm 0.2$ & $11.2 \pm 0.4$ & $17.1 \pm 0.4$ \\
\hline His & $1.3 \pm 0.1$ & $2.4 \pm 0.2$ & $2.0 \pm 0.2$ & $1.4 \pm 0.2$ & $0.6 \pm 0.1$ \\
\hline Arg & $1.1 \pm 0.1$ & $1.6 \pm 0.2$ & $3.0 \pm 0.1$ & $1.5 \pm 0.2$ & $0.5 \pm 0.1$ \\
\hline
\end{tabular}

P-I, Pectin-I; P-II, Pectin-II; HC-I, Hemicellulose-I; HC-II, Hemicellulose-II; C, Cellulose. Values are mean \pm SD $(N=5)$. Measured as cysteic acid. Tryptophan was not measured.

するため，収率は低くなり約 $2 \%$ $\%$ な。

以上の钼察結果から，タイス属の豆のほうがインゲン マメ属の豆よりもアリューロン層が発達し丈夫であるこ とが明らかになった。

2. タイズ種子アリューロン首の紬胞垶中の諸画分の クリシン含有旁と含有岳の比較

ダイス種子のアリューロン層の細胞壁から分餎した諸 画分のアミノ酸組成を Table 1 に示した。グリシンのモ ル\%て比較すると，ペクチンI 画分ては約 $48 \%$ て最も高 く, 次にペクチン II 画分の約 $35 \%$, ヘミセルロース I 画 分の約 13\%, ヘミセルロース II 画分の約 8\%, セルロー ス画分の約 $5 \%$ と值は順に低くなった。一方, へミセル ロースII画分およびセルロース画分はヒドロキシプロ リン含有率が高いのでエクステンシンが多く存在すると 推定された。精製した GRP はグリシンのモル\%が $70 \%$ 近くになるので(1)，タンパク質末精製段階のペクチン I 画分がリシン含有率 $48 \%$ を示すことから，この画分には 相当高い割合で GRP が含まれていることが明らかであ る。

ダイス 1,000 粒から分離したアリューロン層の乾嬠重 量 $2.5 \mathrm{~g}$ 当りの細胞壁のグリシン量は Table 2 に示すよ うに, ペクチンI 画分では $15.0 \mu \mathrm{mol}$, ペクチン II 画分 では $4.5 \mu \mathrm{mol}$ であり, 両者を合わせたペクチン画分と しては $19.5 \mu \mathrm{mol}$ となり, へミセルロース I および II 画
Table 2. Glycine content in several fractions of the cell wall of soybean aleurone layer.

\begin{tabular}{lc}
\hline Fraction & $\begin{array}{c}\text { Glycine } \mu \mathrm{mol} / 2.5 \mathrm{~g} \text { dry } \\
\text { aleurone layer }\end{array}$ \\
\hline Pectin-I & $15.0 \pm 0.4$ \\
Pectin-II & $4.5 \pm 0.4$ \\
Hemicellulose-I & $15.7 \pm 0.5$ \\
Hemicellulose-II & $0.5 \pm 0.1$ \\
Cellulose & $1.2 \pm 0.2$ \\
\hline
\end{tabular}

Values are mean $\pm \mathrm{SD}(N=5)$.

分を合わせた $16.2 \mu \mathrm{mol}$ やルロース画分の $1.2 \mu \mathrm{mol}$ の合計より多くなった。これらの結果から, 細胞壁 GRP の大半はペクチン画分に存在し，しかもそのほとんどは 熱水によって溶解する性質のものであることが明らかに なった。したがって,このようにエクステンシンとは異 なった細胞壁内分布を示す GRP は,タイイスのアリュー ロン層に特異的な細胞壁権成タンパク質として重要な役 割を果たしていると推測される。

3. 各租の豆のアリューロン届のアミノ酸組成とグリ シン含贯の比较

各種の豆種子からアリューロン層組織を採取し，その 組織から得た熱水可溶性画分 (ペクチンI画分)のアミノ 酸組成を Table 3 に示した。いずれの豆においてもグリ 
Table 3. Amino acid composition of fraction solubilized with hot water from aleurone layers of different beans.

\begin{tabular}{lrrrrr}
\hline \hline Amino acid & Soybean & Black soybean & Wild soybean & $\begin{array}{c}\text { Red kidney } \\
\text { bean }\end{array}$ & $\begin{array}{c}\text { Marbled kidney } \\
\text { bean }\end{array}$ \\
\hline Asx & $7.5 \pm 0.2$ & $7.5 \pm 0.2$ & $8.0 \pm 0.2$ & $9.1 \pm 0.2$ & $9.3 \pm 0.2$ \\
Thr & $1.9 \pm 0.2$ & $3.5 \pm 0.1$ & $3.2 \pm 0.2$ & $5.4 \pm 0.3$ & $5.1 \pm 0.2$ \\
Ser & $11.3 \pm 0.2$ & $7.9 \pm 0.2$ & $8.0 \pm 0.1$ & $8.1 \pm 0.3$ & $8.0 \pm 0.2$ \\
Glx & $7.8 \pm 0.4$ & $8.6 \pm 0.4$ & $9.4 \pm 0.2$ & $8.1 \pm 0.3$ & $7.8 \pm 0.1$ \\
Pro & $2.8 \pm 0.2$ & $4.3 \pm 0.3$ & $4.3 \pm 0.2$ & $5.2 \pm 0.2$ & $5.5 \pm 0.2$ \\
Gly & $47.9 \pm 1.1$ & $33.3 \pm 0.8$ & $29.8 \pm 0.7$ & $18.9 \pm 0.5$ & $21.8 \pm 0.5$ \\
Ala & $5.6 \pm 0.1$ & $6.7 \pm 0.3$ & $6.8 \pm 0.2$ & $7.7 \pm 0.2$ & $7.4 \pm 0.1$ \\
l/2Cys & $0.6 \pm 0.1$ & $0.7 \pm 0.1$ & $0.7 \pm 0.1$ & $0.7 \pm 0.1$ & $0.5 \pm 0.1$ \\
Val & $2.0 \pm 0.1$ & $4.3 \pm 0.1$ & $4.5 \pm 0.1$ & $6.4 \pm 0.1$ & $6.0 \pm 0.2$ \\
Met & $0.4 \pm 0.1$ & $1.0 \pm 0.1$ & $1.1 \pm 0.2$ & $1.7 \pm 0.2$ & $1.0 \pm 0.1$ \\
Ile & $1.5 \pm 0.1$ & $3.2 \pm 0.2$ & $3.2 \pm 0.2$ & $4.5 \pm 0.2$ & $4.2 \pm 0.2$ \\
Leu & $1.6 \pm 0.2$ & $3.1 \pm 0.1$ & $4.3 \pm 0.2$ & $7.2 \pm 0.2$ & $6.9 \pm 0.2$ \\
Tyr & $1.3 \pm 0.2$ & $3.3 \pm 0.2$ & $3.7 \pm 0.2$ & $3.2 \pm 0.2$ & $3.6 \pm 0.2$ \\
Phe & $1.1 \pm 0.2$ & $2.7 \pm 0.1$ & $2.8 \pm 0.2$ & $4.3 \pm 0.2$ & $3.9 \pm 0.2$ \\
Lys & $4.4 \pm 0.2$ & $4.4 \pm 0.3$ & $4.5 \pm 0.2$ & $3.6 \pm 0.1$ & $3.4 \pm 0.2$ \\
His & $1.3 \pm 0.1$ & $2.1 \pm 0.1$ & $2.3 \pm 0.1$ & $2.0 \pm 0.2$ & $2.0 \pm 0.1$ \\
Arg & $1.1 \pm 0.1$ & $3.3 \pm 0.1$ & $3.2 \pm 0.2$ & $3.7 \pm 0.1$ & $3.4 \pm 0.2$ \\
\hline \hline
\end{tabular}

Values are mean $\pm \mathrm{SD}(N=5)$. Measured as cysteic acid. Tryptophan was not measured.

Table 4. Amino acid composition of the fraction adsorbed on DEAE-sephadex from hot water-soluble fraction of different beans.

\begin{tabular}{|c|c|c|c|c|c|}
\hline Amino acid & Soybean & Black soybean & Wild soybean & $\begin{array}{c}\text { Red kidney } \\
\text { bean }\end{array}$ & $\begin{array}{c}\text { Marbled kidney } \\
\text { bean }\end{array}$ \\
\hline Asx & $4.6 \pm 0.2$ & $4.9 \pm 0.2$ & $5.7 \pm 0.2$ & $7.7 \pm 0.2$ & $8.0 \pm 0.2$ \\
\hline Thr & $2.5 \pm 0.2$ & $2.3 \pm 0.2$ & $2.9 \pm 0.1$ & $4.6 \pm 0.2$ & $4.3 \pm 0.2$ \\
\hline Ser & $10.7 \pm 0.2$ & $10.8 \pm 0.2$ & $10.5 \pm 0.3$ & $11.3 \pm 0.2$ & $10.1 \pm 0.2$ \\
\hline Glx & $7.9 \pm 0.2$ & $8.1 \pm 0.1$ & $9.4 \pm 0.1$ & $9.1 \pm 0.2$ & $8.6 \pm 0.2$ \\
\hline Pro & $3.1 \pm 0.2$ & $2.1 \pm 0.1$ & $2.3 \pm 0.2$ & $4.2 \pm 0.1$ & $4.5 \pm 0.2$ \\
\hline Gly & $51.2 \pm 0.4$ & $50.4 \pm 0.4$ & $45.3 \pm 0.5$ & $28.9 \pm 0.4$ & $30.4 \pm 0.5$ \\
\hline Ala & $6.4 \pm 0.2$ & $6.3 \pm 0.1$ & $6.3 \pm 0.2$ & $7.0 \pm 0.2$ & $7.0 \pm 0.2$ \\
\hline $1 / 2 \mathrm{Cys}^{\mathrm{a}}$ & $0.5 \pm 0.1$ & $0.5 \pm 0.1$ & $0.6 \pm 0.1$ & $0.4 \pm 0.1$ & $0.4 \pm 0.1$ \\
\hline Val & $2.3 \pm 0.1$ & $2.3 \pm 0.1$ & $2.4 \pm 0.2$ & $4.4 \pm 0.2$ & $4.5 \pm 0.2$ \\
\hline Met & $0.2 \pm 0.1$ & $0.3 \pm 0.1$ & $0.4 \pm 0.1$ & $0.1 \pm 0.0$ & $0.5 \pm 0.1$ \\
\hline Ile & $1.0 \pm 0.1$ & $1.2 \pm 0.1$ & $1.5 \pm 0.2$ & $2.6 \pm 0.2$ & $2.4 \pm 0.2$ \\
\hline Leu & $1.4 \pm 0.1$ & $1.5 \pm 0.1$ & $1.8 \pm 0.1$ & $3.4 \pm 0.2$ & $3.5 \pm 0.2$ \\
\hline Tyr & $1.4 \pm 0.1$ & $2.5 \pm 0.2$ & $3.2 \pm 0.2$ & $5.1 \pm 0.1$ & $4.6 \pm 0.1$ \\
\hline Phe & $0.8 \pm 0.1$ & $0.7 \pm 0.1$ & $1.4 \pm 0.1$ & $5.6 \pm 0.1$ & $5.3 \pm 0.2$ \\
\hline Lys & $3.8 \pm 0.2$ & $3.3 \pm 0.1$ & $3.5 \pm 0.2$ & $2.9 \pm 0.1$ & $2.5 \pm 0.1$ \\
\hline His & $1.5 \pm 0.2$ & $1.4 \pm 0.1$ & $1.4 \pm 0.2$ & $1.8 \pm 0.1$ & $1.8 \pm 0.2$ \\
\hline Arg & $0.8 \pm 0.1$ & $1.3 \pm 0.1$ & $1.5 \pm 0.1$ & $0.9 \pm 0.1$ & $1.6 \pm 0.1$ \\
\hline
\end{tabular}

Values are mean $\pm \mathrm{SD}(N=5) .{ }^{\text {a }}$ Measured as cysteic acid. Tryptophan was not measured.

シンのモル\%が高かったので, いずれの豆のアリューロ

ン層にも GRP が存在することを示唆している。またグ リシン\%はダイス (エンレイ), 黒ダイス (タンバグロ),
ツルマメのダイス属がインゲンマメ(タイショウキント キ) やインゲンマメ (トラマメ) のインゲンマメ属より も高い値になった。 
482

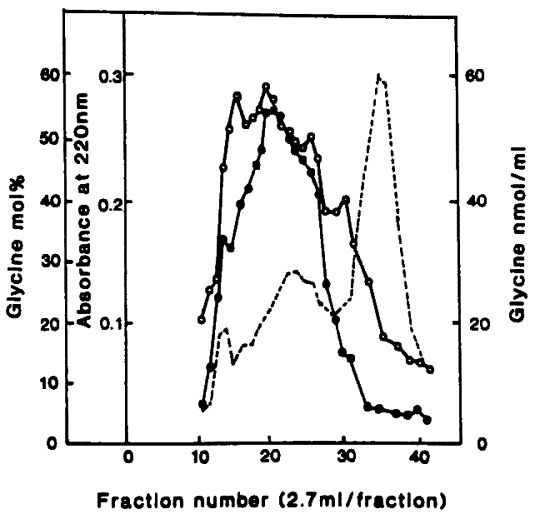

Fig. 2. Elution profile from Sephadex G-100 column of aleurone protein fraction extracted from black soybean.

The fraction eluted from the DEAE-Sephadex column was chromatographed on a Sephadex G-100 column $(1.0 \times 120 \mathrm{~cm})$. O, glycine mol\%; ๑, glycine $\mu \mathrm{mol} / \mathrm{ml} ; \cdots \cdot$, absorbance at $220 \mathrm{~nm}$.

DEAE-セファデックスに吸着したアリューロン居タ ンパク質画分のアミノ酸組成を Table 4 に示した。グリ シン\%はダイス (エンレイ) て約 $52 \%$, 黒ダイス (タン パグロ) て約 $51 \%$ ，ツルマメて約 46\%になり高い值を示 したが, インゲンマメ（タイショウキントキ）やインゲ ンマメ（トラマメ）では 30\%前後に止まった。また表に は示していないが, アリューロン層乾焻重量 (g) あたり の熱水可溶性画分のグリシン量 $(\mu \mathrm{mol})$ を比较すると, インゲンマメ(タイショウキントキ) やインゲンマメ(ト

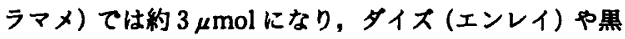
ダイス (タンバグロ) ては約 $6 \mu \mathrm{mol}$ になったのて, イン ゲンマメ属ではダイズ属の約 2 分の 1 至でった。以上 の結果から，いずれの豆のアリューロン届にもGRPは 存在するが,アリューロン層組織あたりに含まれる GRP 重ではダイス属の豆がインゲンマメ属の豆に比べてかな り多いことがわかった。

4. 㬎タイス(タンパグロ), ツルマメ程子のアリュー ロン贯 GRP のゲル渵迎バターンと分子量

豆種子のアリューロン间タンパク實画分についてゲル 減過を行い, Fig. 2, 3 の結果を得た。黒ダイズタンパ グロ) とツルマメではフラクションNo. 16 と No. 20 が

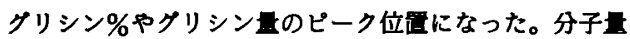
既知のタンパク筫の溶出位置との比较からこれらの GRP の分子サイスを推定すると両者とも約 $60 \mathrm{kDa}$ と 約 $30 \mathrm{kDa}$ に相当した。これらの值はダイス GRP(1) で得 た值と同じであり, $60 \mathrm{kDa}$ の GRP は $30 \mathrm{kDa}$ の GRP の 2 量体と推定した。黒ダイホッルマメ（ダイスの野生

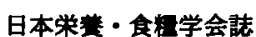

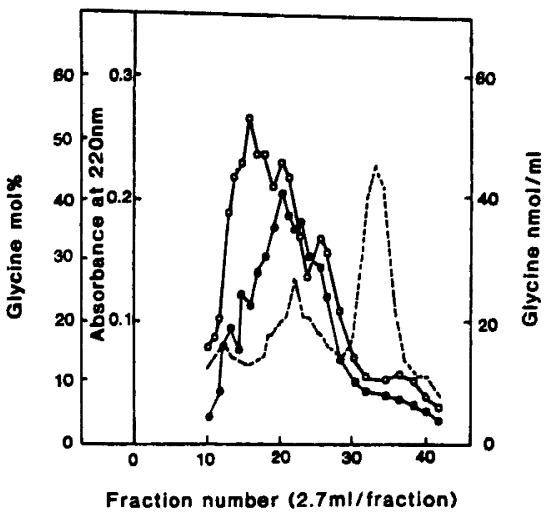

Fig. 3. Elution profile from Sephadex G-100 column of aleurone protein fraction extracted from wild soybean.

The fraction eluted from the DEAE-Sephadex column was chromatographed on a Sephadex G-100 column $(1.0 \times 120 \mathrm{~cm})$. O, glycine mol\%; $\bullet$, glycine $\mu \mathrm{mol} / \mathrm{ml} ; \cdots \cdot$, absorbance at $220 \mathrm{~nm}$.

程) ${ }^{21)}$ に存在する GRP はそのアミノ酸組成や分子サイ スから考えて，タイス GRPに比較的近い性筫のものと 推測される。

以上の結果から，タイス屈植物のアリューロン層が比 較的強固な構造を示し，その細胞壁には $30 \mathrm{kDa}$ の GRP を多く含むことが明らかになった。一般に植物組織の細 胞壁てはエクステンシンが細胞薜の權造強化に役立つ が22), タイス层植物のアリューロン首細胞壁ては GRP が細胞壁粠造強化のために何らかの役割を担っていると 推察した。

\section{要 約}

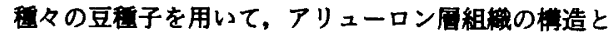
アリューロン居組織に含まれる GRP(高グリシンタンパ ク筫）の含有量を調べ，次に示す結果を得た。

1) ダイス (Glycine max, 品酒エンレイ), 黒ダイス (Glycine max, 品種タンバグロ), ツルマメ(Glycine soja) のアリューロン層細胞壁は, 赤インゲンマメ (Phaseolus vulgaris, 品暞タイショウキントキ), 玨入イン゙ンマメ (Phaseolus vulgaris, 品種トラマメ)のものよりも厚みが 増していた。

2）ダイスのアリューロン層細胞壁に特異的な GRP は主としてペクチン画分に存在した。

3） 3 種のダイスのアリューロン層の熱水可溶性画分 の GRP 含有量は 2 種のインゲンマメのものより高かっ た。

4）ツルマメや黒ダイスから抽出した GRP の推定分 
子サイスはそれぞれダイスと同じ約 $30 \mathrm{kDa}$ であった。 以上の結果から,ダイス属植物のアリューロン層の GRP はアリューロン層の細胞壁権造強化に何らかの役割を 担っていると推察した。

本研究の一部は私学振興財団の大学院重点特別経貫に より行われたので謝意を表します。また本研究を行うに あたり，実殹遂行にご協力いただいた間野利美さんと山 中奈々絵さんに感貄します。さらに実験材料の豆の一部 を提供していただいた大阪市中央区の梅田村商店に厚く 感謝の意を表します。

\section{文献}

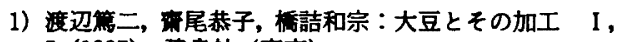
5 (1987), 建帛社 (東京)

2）福田 满, 松井美代子，高岡美津子，角田䗆子，浜渦善

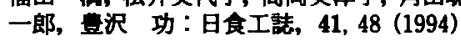

3) Varner, J.E. and Cassab, G.I. : Nature, 323, 110 (1986)

4) Condit, C.M. and Meagher, R.E. : Nature, 323, 178 (1986)

5) Reddy, A.S.N. and Poovaiah, B.H. : Biochem. Biophys. Res. Commun., 147, 885 (1987)

6) Gómez, J., Sánchez-Martínetz, D., Stiefel, V., Igau, J., Puigdomènech, P. and Pagès, M. : Nature, 334,
262 (1988)

7) Keller, B., Sauer, N. and Lamb, C.J. : EMBO J., 7, 3625 (1988)

8) Rohde, W., Rosch, K., Kröger, K., and Salamini, F. : Plant Mol. Biol., 14, 1057 (1990)

9) Ye, Z.-H. and Varner, J.E. : Plant Cell, 3, 23 (1991)

10) Lamport, D.T.A. : Biochemistry, 8, 1155 (1969)

11) Van Holst, G.J. and Varner, J.E. : Plant Physiol., 64, 247 (1984)

12) Wilson, L.G. and Fry, J.C. : Plant Cell Environ., 9, 239 (1986)

13) Hong, J.C., Nagao, R.T. and Key, J.L. : J. Biol. Chem., 265, 2470 (1990)

14) Castonguay, Y., Nadeau, P. and Laberge, S. : Plant Cell Physiol., 34, 31 (1993)

15) Sheng, J., Jeong, J. and Mehdy, M.C. : Proc. Natl. Acad. Sci. U.S.A., 90, 828 (1993)

16) Condit, C.M. : Plant Cell, 5, 277 (1993)

17) Matsui, M., Toyosawa, I. and Fukuda, M. : Biosci. Biotech. Biochem., 58, 1920 (1994)

18) Matsui, M., Toyosawa, I. and Fukuda, M. : Biosci. Biotech. Biochem., 59, 2231 (1995)

19）福田 满：日食工誌, 35, 83 (1988)

20) Cassab, G.I., Nieto-Sotelo, J., Cooper, J.B., Van Holst, G.-J. and Varner, J.E. : Plant Physiol., 77, 532 (1985)

21）前田和美: マメと人間, 49 (1987), 古今贯院 (東京)

22) Cooper, J.B. and Varner, J.E. : Plant Physiol., 76, 414 (1984)

（1995 年 4 月 6 日受理） 